\title{
Freshwater sponges (Porifera, Demospongiae) in a benthic filter feeding community at the Guanacaste Dry Forest, Costa Rica
}

\author{
Cecilia Volkmer-Ribeiro \& Vanessa de S. Machado
}

Museu de Ciências Naturais, Fundação Zoobotânica do Rio Grande do Sul, Caixa Postal nº 1188, 90001-970 Porto Alegre, RS. (cvolkmer@fzb.rs.gov.br; nessabiol@gmail.com)

\begin{abstract}
The freshwater sponges Trochospongilla variabilis Bonetto \& Ezcurra de Drago (1973), Radiospongilla crateriformis (Potts, 1882), Spongilla cenota Penney \& Racek (1968) and Corvoheteromeyenia heterosclera (Ezcurra de Drago, 1974) compose with the sphaerid bivalve Eupera cubensis (Prime, 1865) and several Phylactolaemata bryozoans a benthic filter feeding community living in seasonal lentic and lotic habitats with high Particulate Organic Carbon (POC), low conductivity and acid pH within the Costa Rica Dry Forest biome. The sponge specimens gathered led to the re-description of the four species.
\end{abstract}

KEYWORDS. Freshwater Sponges, Bryozoans, Bivalves, Central America, Dry Forest.

RESUMO. Esponjas continentais (Porifera, Demospongiae) em uma comunidade bêntica filtradora na Floresta Decidual de Guanacaste, Costa Rica. As esponjas de água doce Trochospongilla variabilis Bonetto \& Ezcurra de Drago (1973), Radiospongilla crateriformis (Potts, 1882), Spongilla cenota Penney \& Racek (1968) e Corvoheteromeyenia heterosclera (Ezcurra de Drago, 1974) compõem, com o bivalve esferídeo Eupera cubensis (Prime, 1865) e diversos briozoários Phylactolaemata, uma comunidade bêntica de filtradores em ambientes sazonais lênticos e lóticos com alto Carbono Orgânico Particulado (POC), baixa condutividade e pH ácido no bioma da Floresta Decidual da Costa Rica. Os espécimes de esponjas coligidos conduziram à redescrição das quatro espécies.

PALAVRAS-CHAVE. Esponjas continentais, Briozoários, Bivalves, América Central, Floresta Seca.

The first record of the occurrence of freshwater sponges in Central America and the Antilles was made by MeEK (1908), who assigned Eunapius fragilis (Leidy, 1851) to Guatemala. JONES \& RUTZLER (1975) reported the occurrence of Eunapius carteri (Bowerbank, 1863), Trochospongilla leidii (Bowerbank, 1863) and Trochospongilla horrida (Weltner, 1893), to Panamá. PoIRRIER (1977) refered to a personal communication by Vincent Resh concerning the occurrence of Anheteromeyenia ryderi (Potts, 1882) in Belize. PoIRRIER \& TRABANino (1989), in turn, registered Ephydatia fluviatilis (Linnaeus, 1759) and Spongilla alba (Carter, 1849) in El Salvador; and Sмітн (1994), in a survey of sponges in the Virgin Islands, detected only E. fluviatilis. The latter species was also registered by Murillo \& Mora (1995) in Costa Rica. BASS \& VOLKMER-RIBEIRO (1998) assigned and illustrated Radiospongilla crateriformis (Potts, 1882) in the islands of Barbados and Nevis. More recently, Debrot \& Van-Soest (2001) registered Corvoheteromeyenia heterosclera (Ezcurra de Drago, 1974) and S. alba in the islands of the southern Caribbean, and Manconi \& Pronzato (2005) described Anheteromeyenia cheguevarai in western Cuba and indicated the occurrence of Ephydatia facunda Weltner (1895), $R$. crateriformis and Radiospongilla sp. on the island.

Roush (1999) in announcing the survey of freshwater Bryozoans which he carried out in the Guanacaste Conservation Area, in Costa Rica, remarked the restriction of their occurrences to the Deciduous Forest Area and the occurrence of freshwater sponges in the same habitats. He, preliminarily, identified the sponge genera Radiospongilla Penney \& Racek, 1968, Dosilia Gray, 1867, Corvomeyenia Weltner, 1913,
Trochospongilla Vejdovsky, 1883 and the species Spongilla cenota Penney \& Racek (1968). Roush (2000) published the results of the survey of Bryozoans and sent the sponge material to the senior author for study. The results of that study are now offered and contain the redescription, with the first Scanning Electron Microscopy (SEM) illustrations of $S$. cenota and the gemmule structure of $C$. heterosclera. The paper presents the first register of species of sponges that compete with Bryozoans and sessile bivalves in a freshwater environment. The characteristics are reported of the habitats occupied by this community of benthic, sessile and filter-feeding macro-invertebrates in the area. The common functional adaptations presented by the members of this community are also remarked.

\section{MATERIAL AND METHODS}

The Guanacaste Conservation Area was established in order to protect the Dry and Deciduous Tropical Forest of Costa Rica. The streams originating in this biome are of low order, shallow and slight inclination, and dry during five or six months of the year. The description and map of the collecting sites, organized for the samples of bryozoans in the area, carried out between 1996 and 1997 are found in Roush (2000), together with features of the habitats (temperature, $\mathrm{pH}$, conductivity, current and Particulate Organic Carbon (POC)). The geographical coordinates of the collection sites were furnished by S. A. Roush, in a pers. comm. to the senior author. The species of sponges gathered by S. A. Roush and the object of the present study, were entrusted to the senior author and are thus deposited and catalogued in the Porifera collection of the Museu de Ciências 
Naturais of the Fundação Zoobotânica do Rio Grande do Sul, Porto Alegre, RS, Brazil (MCN-POR). The specimens of the bivalve were identified by Dr. M. C. D. Mansur at Museu de Ciência e Tecnologia, Pontifícia Universidade Católica do Rio Grande do Sul (PUC), Porto Alegre, and catalogued in the Malacological Collection of the Museu de Ciências Naturais of the Fundação Zoobotânica do Rio Grande do Sul (MCN-MOL). Preparations of dissociated spicules of the sponges were obtained according to VOLKMER-RIBEIRO (1985) and VOLKMERRIBEIRO \& TURCQ (1996), for studies with, respectively, light optical and Scanning Electron Microscopy (SEM). The SEM photographs were obtained at the Electron Microscopy Laboratory of Universidade Luterana do Brasil (ULBRA), in Canoas, Rio Grande do Sul. Fifty measurements were made of each spicule category, considering all the specimens of each one of the species. Digital photographs of representative specimens of each of the four sponge species as well as of the bivalves were also produced.

\section{RESULTS AND DISCUSSION}

The identification of the collection of sponges made by S. A. Roush, revealed the occurrence of Trochospongilla variabilis Bonetto \& Ezcurra de Drago (1973), $R$. crateriformis, S. cenota and C. heterosclera. The species were found in lentic and lotic environments of small proportions, restricted to the area of the Pacific Dry Forest of Costa Rica and characterized by water temperatures of $23^{\circ} \mathrm{C}, \mathrm{pH} 5.5$, specific condutivity of $60 \mu \mathrm{S}$, POC of 810 to $1580 \mathrm{mg} . \mathrm{cm}^{-3}$ (Roush, 2000). Together with the specimens of some sponges, several individuals of the sessile bivalve Eupera cubensis (Prime, 1865) (Mollusca, Bivalvia, Sphaeridae) were found. Species of Phylactolamatae bryozoans were sampled and identified by Roush (2000) in these environments: Fredericella browni (Rogick, 1941) and some belonging to Plumatella Lamarck, 1816. Table I shows the places where sponges occurred alone, with bryozoans or with bryozoans and the bivalve.

\section{Radiospongilla crateriformis (Potts, 1882) (Figs. 1-3, 8-13)}

Meyenia crateriformis Pоттs (1882):12; Роттs (1887):228, pl. V. Fig. VI, pl. X, fig. V.

Radiospongilla crateriformis PENNEY \& RACEK (1968):66, pl. 5, figs. 1-3, pl. 6, figs. 1, 2 (and synonymy); VolKMER-RIBEIRo (1981): 88; Volkmer-Ribeiro \& TraVeset, 1987:229; Poirrier (1982):59; Bass \& Volkmer-Ribeiro (1998): 124 figs. 1-5; MAnconi \& PronZato (2005): 3245, fig. 4.

Material Examined. COSTA RICA, Guanacaste, Guanacaste Conservation Area: Maritza Sector, temporary stream, 19.VIII.1996, S. A. Roush leg. (MCN-POR 6989); Santa Rosa Sector, Rio Cuajiniquil (10 50 '24,45', N 85'37'09,045',W), 30.VII.1996, S. A. Roush leg. (MCN-POR 6998); 25.III.1997 (MCN-POR 6994); Temporary Pond $\left(10^{\circ} 50^{\prime} 21,816^{\prime \prime} \mathrm{N}\right.$ 85³7'29,929'”W), XII.1996, S. A. Roush leg (MCN-POR 6995); 01.VIII.1996, S. A. Roush leg. (MCN-POR 6996); 26.III.1997, S. A. Roush leg. (MCN-POR 6997).

Description. Sponges forming yellowish, spherical, fragile crusts $2.5 \mathrm{~cm}$ wide and $1 \mathrm{~cm}$ high with large and conspicuous oscules (MCN-POR 6989; Figs. 1, 2); or shallow, grayish, stouter crusts $3 \mathrm{~cm}$ wide and $0.2 \mathrm{~cm}$ high
(MCN-POR 6995; Fig. 3) on the bark of submerged logs. Skeleton reticulated, anisotropic, from the base to the top, with very slender fibers in the spherical specimens. Megascleres slender, straight to slightly curved, abruptly pointed anfioxea with minute straight spines sparsely ditributed along the spicule (Fig. 8). Megascleres length: from $239.02 \mu \mathrm{m}$ to $446.96 \mu \mathrm{m}$ (average $344.3 \mu \mathrm{m}$ ); width: 7.02 $\mu \mathrm{m}$ to $17.03 \mu \mathrm{m}$ (average $12.10 \mu \mathrm{m}$ ). Microscleres absent. Gemmoscleres in one series of slender, straight to sligthly curved, strongly spined anfistrongyla, the shorter about half the length of the longer ones (Figs. 8, 9), with larger incurved spines grouped around the extremities of the spicule, thus forming small umbonate rotules (Fig. 10). Gemmoscleres length: from $79.97 \mu \mathrm{m}$ to $123.10 \mu \mathrm{m}$ (average $97.71 \mu \mathrm{m}$ ); width: $5.10 \mu \mathrm{m}$ to $8.23 \mu \mathrm{m}$ (average $6.83 \mu \mathrm{m}$ ). Gemmules extremely abundant (Figs. 1,2), distributed from the base to the surface, large, pear shapped (Fig. 11), the older ones grayish and the new ones whitish. Foraminal tube long, contained inside the thick pneumatic coat, gemmoscleres radially embedded in the pneumatic coat up to the collar which surrounds and surpassess the foraminal tube (Figs. 11, 12). Pneumatic coat consisting of a network of irregular and slender spongin fibers, thus producing also irregular air cameras (Fig. 13). Outer gemmular coat thin, gemmular surface crateriform, each crater containing the starlike rotule of a gemmosclere (Fig. 11).

Remarks. The species occurred with globose, yellowish, fragile, spongin rich specimens in lentic environment (MCN-POR 6995; Figs. 1, 2); and grayish, harder, spicule rich shallow crusts in lotic (MCN-POR 6998; Fig. 3) environments at the Guanacaste Dry Forest. The fragile specimens conform to the description offered by RiOJA (1953) for the ones, obtained from $\mathrm{km} 286$ of the road Mexico-Tuxpan. Also, his drawings of the gemmule structure of $R$. crateriformis have now been confirmed in every detail with SEM illustration. This is the third record of $R$. crateriformis for the Caribbean Region, following that of BASS \& VOLKMER-RIBEIRO (1998) for Barbados and that of Manconi \& Pronzato (2005) for Cuba. The occurrence of $R$. crateriformis in Caribbean organically enriched seasonal habitats may now be established as common place (BASS \& VOLKMER-RIBEIRO, 1998; MANCONI $\&$ Pronzato, 2005) and one not too far away from the the Brazilian savanna (cerrado) seasonal ponds where $R$. amazonensis Volkmer-Ribeiro \& Maciel (1983) is also commonly found VOLKMER-RIBEIRO et al. (1998).

The sponge MCN-POR 6994, from River Cuajiniquil was found associated to several specimens of the sessile sphaerid bivalve E. cubensis (Fig. 35, Tab. I), whilst the sponges MCN-POR 6995 and 6996, from temporary pond, Santa Rosa Sector, were found associated to the bryozoans Plumatella sp.1 and Plumatella sp.3 (Tab. I).

\section{Trochospongilla variabilis Bonetto \& Ezcurra de Drago, 1973 \\ (Figs. 4, 14-19)}

Trochospongilla variabilis BonetTo \& EzCURRA DE DRAgO (1973):15, fig.11; VolKMER-RIBeIRo (1981):89; (1992):323, fig. 3; VOLKMERRibeiro et al. (1998):410; TAVAREs et al. (2003):176, fig. 11 VolKMER-Ribeiro \& Batista (2007):138, fig. 12.

Material examined. COSTA RICA, Guanacaste: Carretera Cuajiniquil (Guanacaste Conservation Area, temporary marsh, 1057'06,18'N 85³7'01,64'”W), 27.VIII.1996, S. A. Roush leg. (MCN-POR 6987, 6988). 
Description. Sponges forming small, shallow, extremely fragile crusts on the bark of submerged logs (Fig. 4). Pinacoderm bright whitish covering the inner brownish skeleton. Skeleton with parchment structure, the megascleres tangentially criss-crossed on the substrate, skeleton fibers absent, spongin scarce. Megascleres small, slender, slightly curved, spiny anfioxea, with quite variable sizes and gradually tapering very sharp extremities, spines minute and sparsely distributed, the ones at the extremities curved towards the middle of the sclere (Figs. 14, 15). Megascleres length: from $327.45 \mu \mathrm{m}$ to $538.35 \mu \mathrm{m}$ (average $454.91 \mu \mathrm{m}$ ); width: $10.73 \mu \mathrm{m}$ to $23.31 \mu \mathrm{m}$ (average $16.48 \mu \mathrm{m}$ ). Microscleres absent. Gemmoscleres birrotulates with both rotules turned outwords, the inner one containing the outer one; inner rotule large flat, with thin, smooth border; outer rotule small, cup shapped, border thick, its outer profile circular and smooth and its inner portion undulated, flower like, microspined and containing the rounded projection of the shaft; shaft smooth, slendering towards its central portion (Figs. 14, 16). Gemmoscleres length: from $13.92 \mu \mathrm{m}$ to 17.93 $\mu \mathrm{m}$ (average $16.44 \mu \mathrm{m}$ ); width: $2.45 \mu \mathrm{m}$ to $5.75 \mu \mathrm{m}$ (average $3.93 \mu \mathrm{m})$. Gemmules minute, spherical or concave, sparsely distributed along the skeleton (Figs. 17, 18). Foraminal tube short, provided or not with an irregularly shapped collar of spongin. Inner gemmular coat in two thin layers; pneumatic coat consisting of a regular netwwork of spongin fibers producing also regular spherical air cells (Fig. 19). Gemmoscleres radially embedded in the pneumatic coat, the outer rotules and the shaft extremity they contain reaching beyond the thick outer coat (Figs. 17, 18, 19).

Remarks. This is the first time T. variabilis is reported for the Caribbean Area. The species was sampled only from the temporary marsh at the Guanacaste Dry forest, which conforms to its known occurrence in temporary peat bog ponds in the Brazilian savanna and savanna remnants inside the Amazonian Forest (VolKMER-Ribeiro et al., 1998). The studied specimens also conform the characteristics presented by the brazilian materials (VOLKMER-RIBEIRO, 1992).

The T. variabilis specimens (MCN-POR 6987 and
6988) were found associated to the bryozoans Plumatella sp.5 and Plumatella sp.6 (Tab. I).

\section{Spongilla cenota Penney \& Racek, 1968}

(Figs. 5, 6, 20-26)

Spongilla cenota Penney \& RACEK (1968):18, pl. I, figs. 8-10, 16 (and sinonymy); PoIrrier (1976):207, fig. 3; (1982):59; Frost (1991):120, fig. 4.23 .

Material examined. COSTA RICA, Guanacaste: Santa Rosa Sector (Rio Cuajiniquil, Guanacaste Conservation Area, $10^{\circ} 50$ '24,45'N 85'37'09,045' W), 13.VIII.1996, S. A. Roush leg. (MCN-POR 6990, 6993).

Description. Sponge forming thin, stout, whitish crusts, up to $3 \mathrm{~cm}$ in diameter, on rock fragments (Figs. 5, 6). Skeleton reticulated, isodictyal, grayish, capped by a conspicuous, whitish pinacoderm charged with a dense incrustation of microscleres. Oscular appertures abundant and conspicuous. Megascleres are stout, straight to curved, microspined oxeas, with abruptly pointed extremities (Figs. 20, 21). Megascleres length: from $390.12 \mu \mathrm{m}$ to $677.10 \mu \mathrm{m}$ (average $552.72 \mu \mathrm{m}$ ); width: $13.49 \mu \mathrm{m}$ to $31.03 \mu \mathrm{m}$ (average $20.58 \mu \mathrm{m}$ ). Microscleres extremely abundant, slender, slightly curved, spiny oxeas, all spines capped by a rosette of microspines (Figs. 20, 22). Microscleres length: from 78.60 $\mu \mathrm{m}$ to $137.63 \mu \mathrm{m}$ (average $106.80 \mu \mathrm{m}$ ); width: $1.90 \mu \mathrm{m}$ to 4.70 $\mu \mathrm{m}$ (average $3.08 \mu \mathrm{m}$ ). Gemmoscleres are short, stout, spiny oxeas, about $1 / 2$ to $2 / 3$ the lenght of the microscleres, straight to slightly curved, covered by large spines curved towards the middle part of the sclere, their extremities split into a few smaller spines (Figs. 20, 23). Gemmoscleres length: from 60.33 $\mu \mathrm{m}$ to $86.20 \mu \mathrm{m}$ (average $73.76 \mu \mathrm{m}$ ); width: $8.39 \mu \mathrm{m}$ to 18.62 $\mu \mathrm{m}$ (average $12.23 \mu \mathrm{m})$. Gemmules extremely abundant, distributed throughout the skeleton, but in a closer arrangement towards the basal part of the sponge; large, withish, tuberculated due to irregular projections of the thick, pneumatic and outer coat layers; gemmular surface hispid due to the projection of gemmoscleres extremities or incrusted slanting megascleres (Figs. 24, 25). Gemmoscleres sparsely and irregularly embedded in the pneumatic and outer coat layers (Fig. 26). Inner gemmular coat in two

Table I. Distribution of the freshwater sponges, the bivale Eupera cubensis (Prime, 1865) and Phylactolamatae bryozoans in Guanacaste Dry Forest, Costa Rica. Bryozoan identification quoted upon Roush (2000) (MCN-POR: Porifera Collection, Museu de Ciências Naturais, Fundação Zoobotânica do Rio Grande do Sul).

\begin{tabular}{|c|c|c|c|c|}
\hline MCN-POR & Habitat & Sponge species & Bryozoan species & Sphaerid bivalve \\
\hline 6987 & & $\begin{array}{c}\text { Trochospongilla variabilis } \\
\text { Bonetto \& Ezcurra de Drago, } 1973\end{array}$ & Plumatella sp.5 & - \\
\hline 6988 & 1- Temporary marsh, & T. variabilis & Plumatella sp.6 & - \\
\hline 7784 & Carretera Cuajiniquil & $\begin{array}{l}\text { Corvoheteromeyenia heterosclera } \\
\text { (Ezcurra de Drago, 1974) }\end{array}$ & - & - \\
\hline 7785 & & C. heterosclera & - & - \\
\hline 6989 & $\begin{array}{l}2 \text { - Temporary stream, } \\
\text { Maritza Sector }\end{array}$ & $\begin{array}{l}\text { Radiospongilla crateriformis } \\
\text { (Potts, 1882) }\end{array}$ & - & - \\
\hline 6990 & \multirow{7}{*}{$\begin{array}{l}3 \text { - Rio Cuajiniquil, } \\
\text { Santa Rosa Sector }\end{array}$} & Spongilla cenota & & \\
\hline & & Penney \& Racek, 1968 & - & - \\
\hline 6993 & & S. cenota & Plumatella sp.1 & - \\
\hline 6991 & & C. heterosclera & Plumatella $\mathrm{sp} .2$ & $\begin{array}{l}\text { Eupera cubensis } \\
\text { (Prime, } 1865)\end{array}$ \\
\hline 6992 & & C. heterosclera & $\begin{array}{l}\text { Fredericella browni } \\
\quad \text { (Rogick, 1941) }\end{array}$ & - \\
\hline 6994 & & $R$. crateriformis & - & E. cubensis \\
\hline 6998 & & R. crateriformis & - & - \\
\hline 6995 & \multirow{3}{*}{$\begin{array}{l}4 \text { - Temporary Pond, } \\
\text { Santa Rosa Sector }\end{array}$} & R. crateriformis & Plumatella sp.1 & - \\
\hline 6996 & & R. crateriformis & Plumatella sp.3 & - \\
\hline 6997 & & R. crateriformis & - & - \\
\hline
\end{tabular}


layers. Pneumatic coat consisting of a quite close regular network of thin spongin fibers producing regular, minute, corklike spherical air cameras. Foramen lacking a foraminal tube and placed in a large irregular depression of the pneumatic coat (Figs. 24, 25).

Remarks. This is the third and most southerly record of $S$. cenota in the Caribbean area. The species was originally registered for the Xtoloc Cenote, Yucatan (Mexico) and next for the Everglades (Florida), in a collection carried out by POIRRIER (1976), who reports the collecting site, The Tamiami Canal, off U.S. Hwy 41, to be related to limestone rocks. So are the Yucatan Cenotes, thus suggesting a preference of $S$. cenota for clear, alkaline, slow running waters. Again in the Guanacaste Protected Area the sponge was found only in the Cuajiniquil River, however in a quite low pH (Roush, 2000). The present studied specimens conform in all details to the original description. POIRRIER (1976) after a comparative study of materials of S. alba, Spongilla wagneri Potts, 1889 and
S. cenota stablished $S$. alba (containing $S$. wagneri in its synonymy) as a species apart of $S$. cenota, on account of the gemmular structure, gemmoscleres and habitat characteristics presented by the two species. The hypothesis put forth by PENNEY \& RACEK (1968) that the materials from Cenote Xtoloc they described as $S$. cenota (and which OLD, 1936 had previously identified as Spongilla lacustris) might represent a distant population of $S$. alba was thus refuted by POIRRIER (1976).

The specimen MCN-POR 6993, from River Cuajiniquil, was found associated to specimens of the bryozoan Plumatella sp.1 (Tab. I).

\section{Corvoheteromeyenia heterosclera (Ezcurra de Drago, 1974) \\ (Figs. 7, 27-34)}

Corvomeyenia heterosclera EzCURRA DE DRAGo (1974):234-237, figs. 1,2 .
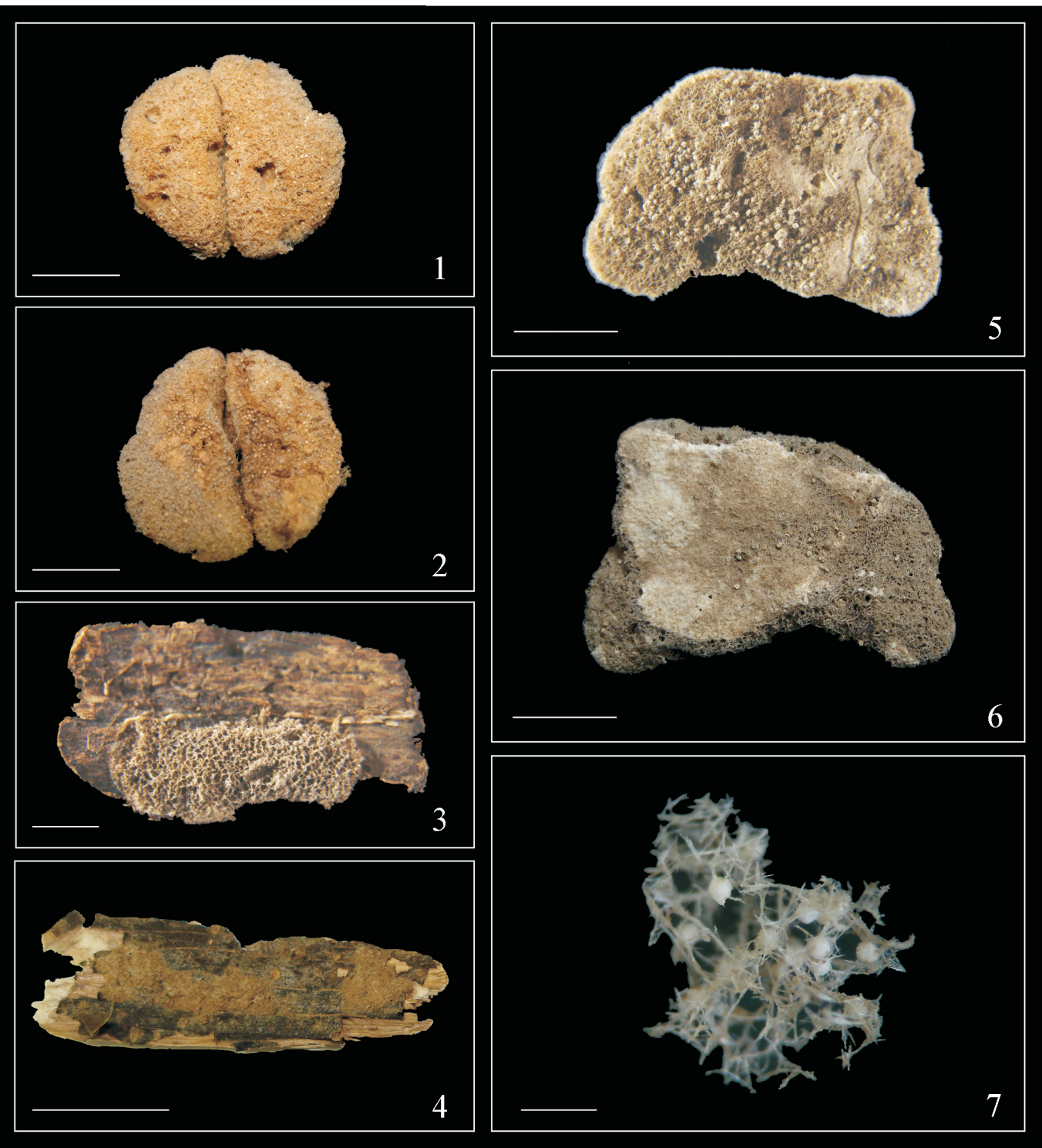

Figures 1-7. 1-3, Radiospongilla crateriformes (Potts, 1882): 1, upper surface of yellowish specimen (MCN-POR 6989); 2, lower surface of yellowish specimen (MCN-POR 6989); 3, grayish specimen on the substrate (MCN-POR 6995); 4, Trochospongilla variabilis Bonetto \& Ezcurra de Drago, 1973 (MCN-POR 6988); 5,6, Spongilla cenota Penney \& Racek, 1968 (MCN-POR 6990); 5, lower surface of specimen; 6, upper surface of specimen; 7, Corvoheteromeyenia heterosclera (Ezcurra de Drago, 1974) (skeleton with gemmules; MCN-POR 6991); Scales: $1 \mathrm{~cm}$. 
Corvoheteromeyenia heterosclera EzCURRA DE DRAGo (1979):113117, figs. 1-6; VolKMER-Ribeiro et al. (1999):646-648, fig. 3; Volkmer-Ribeiro \& Pauls (2000):14-16, fig. 6; Debrot \& VanSoest (2001):90,91, fig. 2; Volkmer-Ribeiro \& Machado (2007):158-160, figs. 1, 5-8, 21, 22.

Dosilia sp. Roush (1999):540.

Corvomeyenia sp. Roush (1999):540.

Material examined. COSTA RICA, Guanacaste, Guanacaste Conservation Area: Carretera Cuajiniquil, temporary marsh (1057'06,18'N 85³7'01,64'W), 27.VIII.1996, S. A. Roush leg. (MCN-POR 7784, 7785); Santa Rosa Sector, Rio Cuajiniquil (1050'24,45'N 8537'09,045'W), 24.III.1996, S. A. Roush leg. (MCN-POR 6991); 31.VII.1996, S. A. Roush leg. (MCN-POR 6992).

Description. The material MCN-POR 6991 corresponds to numerous gemmules and small fragments of an extremely gemmuliferous open reticulum (Fig. 7), previously encrusted on small pieces of charcoal. Skeleton with rarely discernible primary fibers which project at the sponge surface, secondary fibers ill defined. Megascleres are smooth, slender, straight to slightly curved anfioxea with gradually sharpened extremities (Fig. 27). Megascleres length: from $279.35 \mu \mathrm{m}$ to $442.15 \mu \mathrm{m}$ (average $366.93 \mu \mathrm{m}$ ); width: $10.36 \mu \mathrm{m}$ to $22.94 \mu \mathrm{m}$ (average $17.23 \mu \mathrm{m})$. Microscleres in two classes: one of small spiny oxeas (Fig. 27) with larger spines at the middle portion, some of these oxeas may present the micro-rotules described for the species; length: from $62.13 \mu \mathrm{m}$ to 137.60 $\mu \mathrm{m}$ (average $99.27 \mu \mathrm{m}$ ); width: $3.53 \mu \mathrm{m}$ to $6.86 \mu \mathrm{m}$ (average $5.10 \mu \mathrm{m})$; the other, of tiny, slender anfidiscs with straight, spiny shafts and small umbonate rotules deeply cut in a small and irregular number of minute hooks, curved towards the shaft (Fig. 28); length: from $10.64 \mu \mathrm{m}$ to 24.92 $\mu \mathrm{m}$ (average $17.13 \mu \mathrm{m}$ ); width: $1.90 \mu \mathrm{m}$ to $2.73 \mu \mathrm{m}$ (average $2.12 \mu \mathrm{m}$ ); this second class of microscleres may be absent. Gemmoscleres in one class of birotulates with little variation in lenght, rotules almost flat, smooth, with
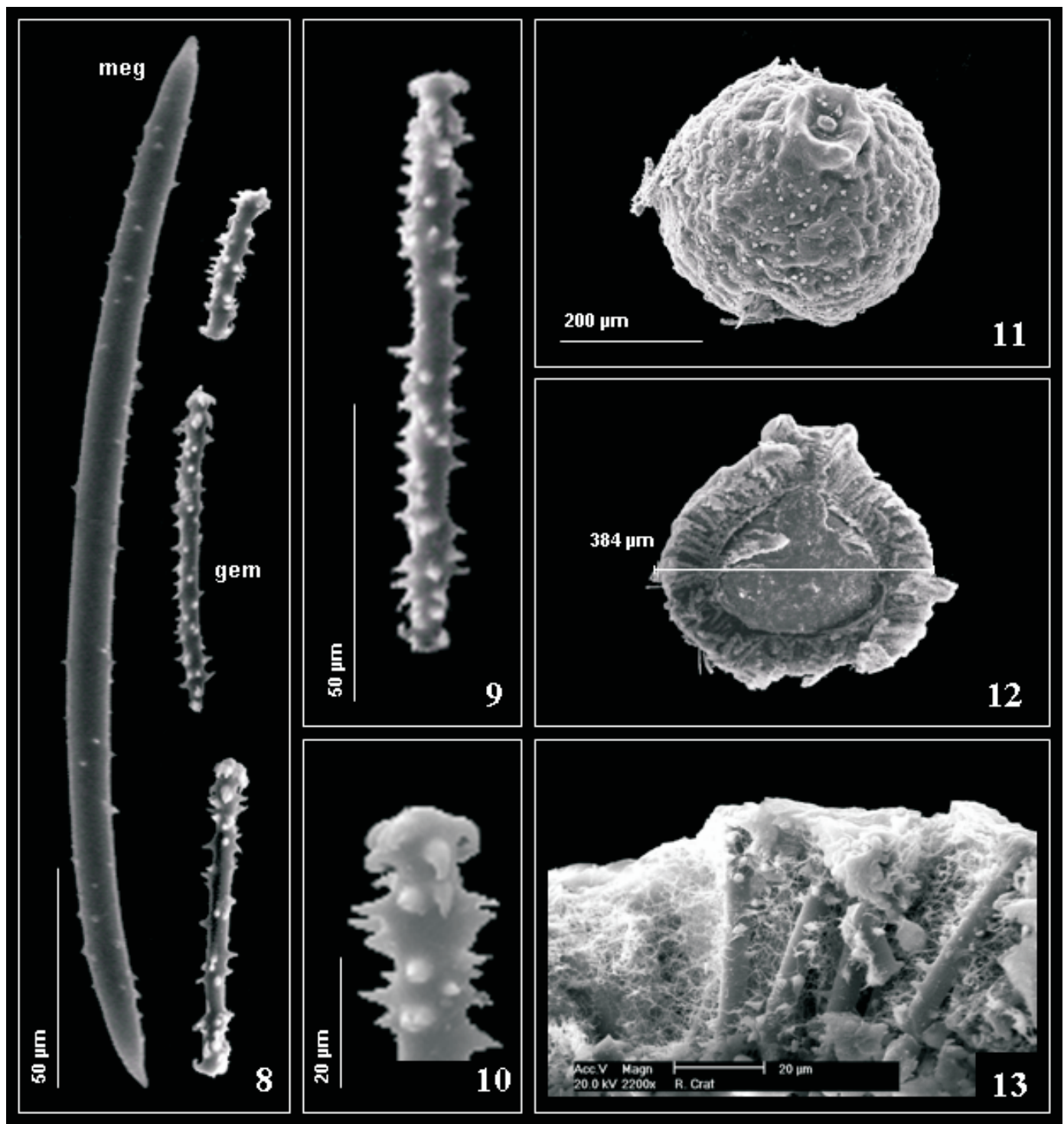

Figures 8-13. Radiospongilla crateriformes (Potts, 1882), SEM illustration of spicules and gemmules: 8, megasclere and gemmoscleres; 9, gemmosclere; 10, detail of the gemmosclere extremity; 11, gemmule showing the crateriform gemmular surface and the collar around the foraminal tube; 12, cross section of the gemmule with the long foraminal tube; 13 , detail of the pneumatic layer of the gemmule. (meg, megascleres; gem, gemmoscleres). 
borders regularly cut in small teeth, shaft with abundant, large, regular, straight, acute spines (Figs. 27, 29, 30, 31). Gemmoscleres length: from $83.01 \mu \mathrm{m}$ to $102.41 \mu \mathrm{m}$ (average $93.73 \mu \mathrm{m}$ ); width: $4.90 \mu \mathrm{m}$ to 7.55 $\mu \mathrm{m}$ (average $6.23 \mu \mathrm{m}$ ). Gemmules abundant, large, spherical, or concave (Fig. 32), whitish, distributed along the whole skeletal network. Foraminal tube short, with an expanded flower-like collar sustained by slanting gemmoscleres (Figs. 32, 33). Gemmoscleres radially embedded in the thick pneumatic coat, the longer ones projecting beyond the gemmule surface (Fig. 34). Pneumatic coat consisting of a quite dense network of thin spongin fibers producing regular, minute, cork-like spherical air cameras. Outer gemmular coat absent. Inner gemmular coat in two layers (Fig. 34).

Remarks. All the studied materials indicate that the sponge is investing its short seasonal life time in the production of gemmules instead of fully developed specimens. MCN-POR 7784 is a small, initial, brownish crust of the sponge, devoid of gemmules, but with conspicuous slender primary fibers. The specimen shares the substrate with $T$. variabilis (MCN-POR 6987). The preparation of a little part of the material revealed the presence of megascleres, a few young gemmoscleres, identical to those of MCN-POR 6991 and a large amount of the tiny anfidisc microscleres which tipify the species, but the spiny oxeas microscleres are missing. The specimen MCN-POR 7785 consists of a slide with the microscopical preparation of a single gemmule found close to the above quoted specimen of $T$. variabilis. The specimen MCN-POR 6992 which comprises only sparse megascleres and microscleres sticking to rocky substrate was identified by Roush (1999) as Dosilia sp. The author probably did not know at the time of the existence of genus Corvoheteromeyenia Ezcurra de Drago, 1979, reason why he took the small spiny oxeas microscleres with larger spines at the middle portion present in MCNPOR 6992 for microscleres of genus Dosilia. The same reason must have underlined his identification of the Corvoheteromeyenia materials as Corvomeyenia.

Several specimens of the native, small, sessil, Sphaerid bivalve E. cubensis (Fig. 35) and specimens of the bryozoans Plumatella sp.2 and F. browni (Tab. I) were found mingled with the crusts of respectively the speciments $C$. heterosclera (MCN-POR 6991 and 6992), at River Cuajiniquil.

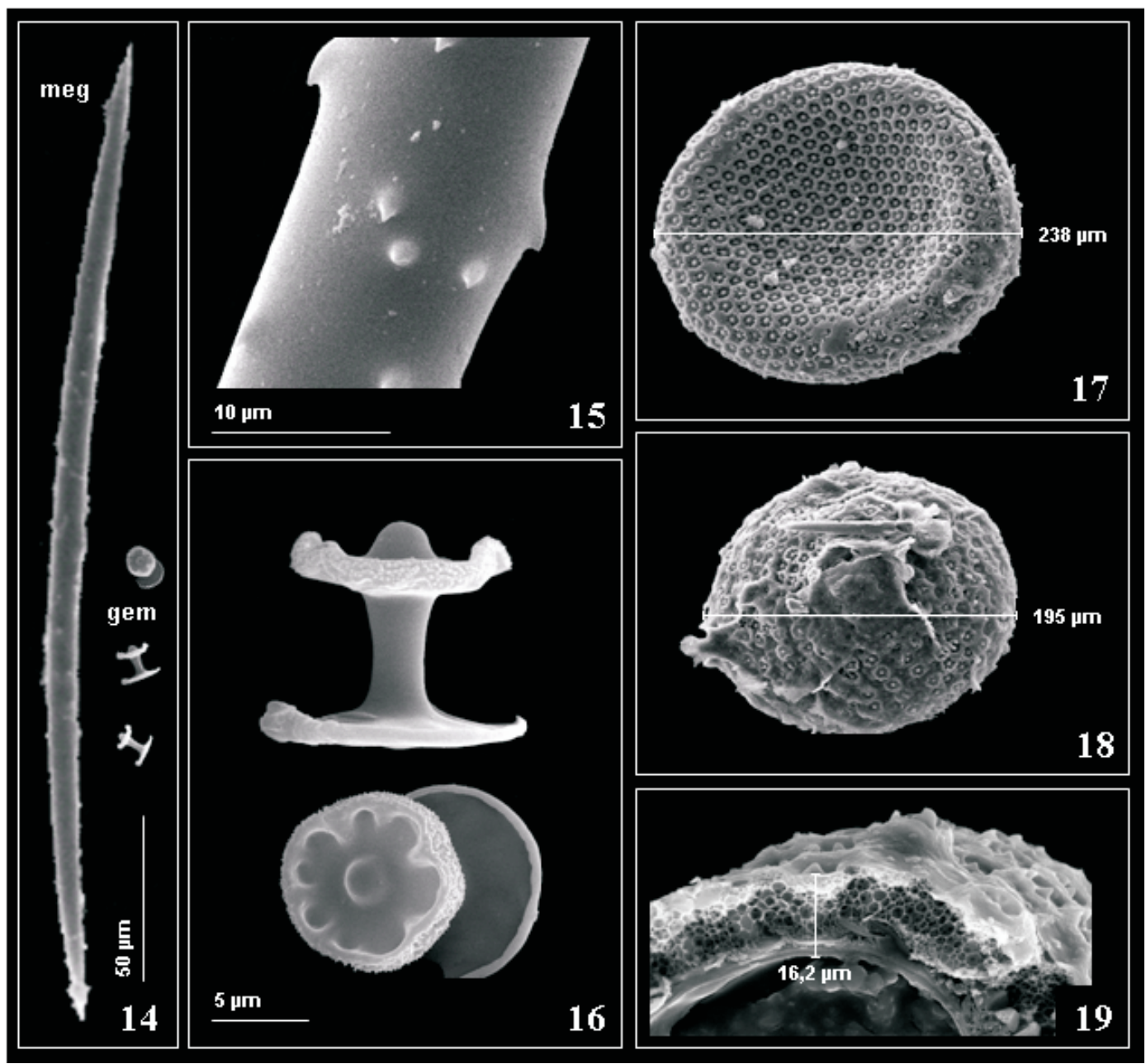

Figures 14-19. Trochospongilla variabilis Bonetto \& Ezcurra de Drago, 1973, SEM illustration of spicules and gemmules: 14, megasclere and gemmoscleres; 15, detail of the megasclere; 16, gemmosclere seen in profile and upper rotule of gemmosclere; 17, gemmular surface; 18, upper surface of the gemmule with foraminal collar; 19, section of the gemmular wall showing the inner, the pneumatic and the outer gemmular coats. (meg, megascleres; gem, gemmoscleres). 


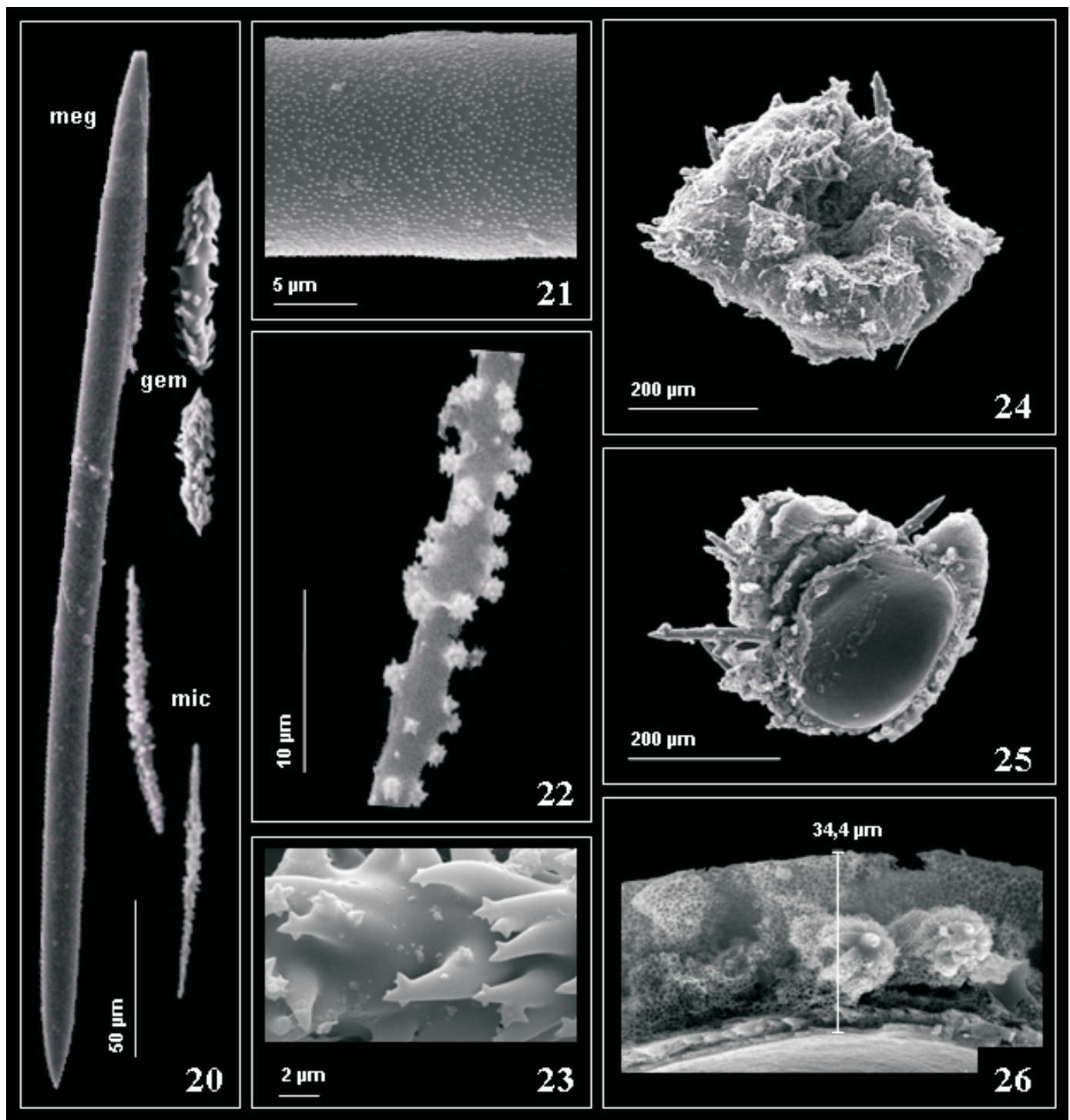

Figures 20-26. Spongilla cenota Penney \& Racek, 1968, SEM illustrations of spicules and gemmules: 20, megasclere, microscleres and gemmoscleres; 21, detail of the microspined surface of the megascleres; 22, detail of the spines on the microsclere; 23 , detail of the spines on the gemmoscleres; 24, the irregular shape of the gemmule and of the foraminal apperture; 25, cross section of the gemmule showing the random incrusting of the gemmoscleres; 26, section of the thick pneumatic layer with its minute air spaces and the projection of the extremities of two gemmoscleres. (meg, megascleres; mic, microsclere; gem, gemmoscleres).

The taxonomic composition of the community of sponges discovered is distinct from those registered to date for Central America and the Caribbean islands (MANConi \& PRonZato, 2005) due to the present reporting of $S$. cenota and $T$. variabilis. The present extension of the distribution of S. cenota in the Caribean Region, allied to the confirmation of its specif status grants this species and $A$. cheguevari the condition of the two only endemic continental sponges in the Caribean Region. In what respects the surveyed sponges there is a strong similarity with the sponge community subjected to drastic seasonality in the northeast of Brazil, as seen in the Lençóis Maranhenses National Park, in Maranhão State (VoLKMER-RIBEIRo et al., 1999), where sponge assemblies typical of the temporary savannah lakes (in which occur $T$. variabilis and $R$. amazonensis) compete with those typical of the coastal dune region (with C. heterosclera).
The detected sponge species point to a relatively biodiverse fauna, adapted to both lentic and lotic environments, but with the common characteristic of the seasonality imposed by the region of the Pacific Dry Forest in the Guanacaste Conservation Area (GCA). Comparison of the results obtained show that $R$. crateriformis and $C$. heterosclera were able to colonize both lentic and lotic habitats, while T. variabilis was restricted to the lentic environment, and $S$. cenota to the lotic environment. For this reason, the former two species are recorded as having the widest distribution within the Guanacaste protection area.

One of the most important findings of the survey carried out by Roush (2000) was the absence of bryozoans in permanent rivers, originating from cloud and rain forest, with clear acidic water and low levels of Particulate Organic Carbon (POC). The bryozoans in the GCA were found 


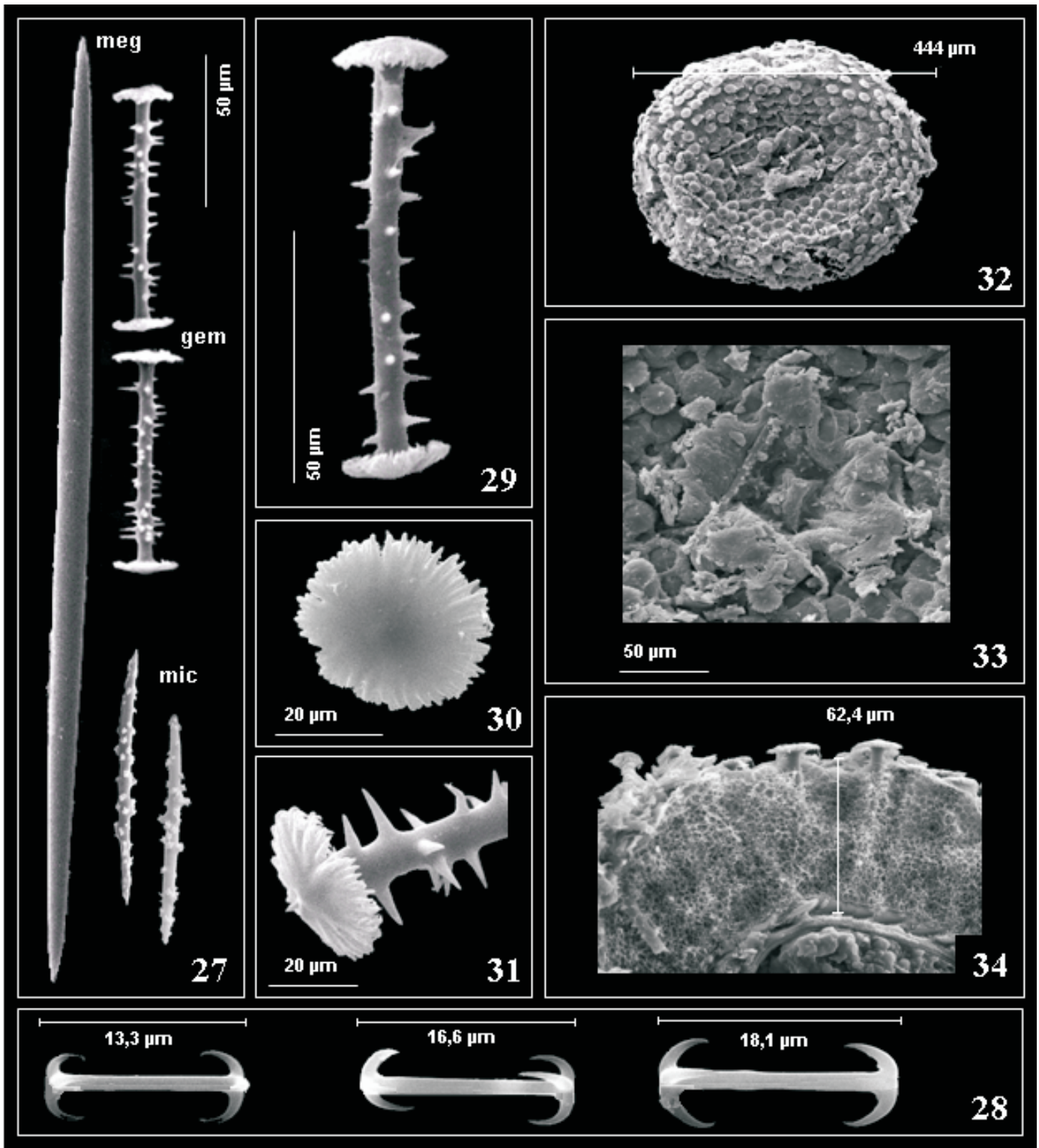

Figures 27-34. Corvoheteromeyenia heterosclera (Ezcurra de Drago, 1974), SEM illustrations of spicules and gemmules: 27, megasclere, large microscleres and gemmoscleres; 28, small microscleres; 29, gemmosclere; 30,31, details of the rotule of the gemmosclere; 32, gemmule and expanded collar around the foraminal tube; 33, detail of the collar of the foraminal tube; 34, detail of the pneumatic layer of the gemmule. (meg, megasclere; mic, microsclere; gem, gemmoscleres).

exclusively in the Dry Forest in small, shallow rivers and lakes subjected to periods of 5 to 6 months of drought. The rivers are characterised by turbidity, acidity, little current and high levels of POC. Obviously, these characteristics fulfil the habitat requirements of the three elements of this community of filter feeders, including the sponges and bivalves surveyed.

The detected association of sponges, bryozoans and bivalves at the River Cuajiniquil collecting site (Tab. I), suggests the presence of a filter feeding community consisting of three phyla of benthic macroinvertebrates in the Atlantic Dry Forest of Costa Rica. These results are the first record of a community of freshwater filterfeeding, benthic, sessile and seasonal macroinvertebrates, composed of sponges, bryozoans and bivalves. Frost (1991), when referring to the competition for substrate between continental sponges and other organisms, highlights his personal notes regarding sponges covering and killing colonies of bryozoans. The occurrence of sponges and bryozoans on the submerged parts of macrophytes, particularly the stalks of the water hyacinths Eichhornia azurea and E. crassipes (Pontederiaceae) Solms-Laubach is a common place in areas of preserved floating meadows like the PacayaSamiria National Reserve (Loreto, Peru) and the Jacuí Delta Park (Rio Grande do Sul State, Brazil; C. VolkmerRibeiro, pers. obs.). Nevertheless, in the Guanacaste Deciduous Forest, the environments and substrate appear to be very different from those of floating meadows, as the sponges, bryozoans and bivalves encrust preferably woody or leafy material fallen from the shoreline vegetation within the environments of marshes or small rivers existing in the area. VOLKMERRIBEIRO \& DE ROSA-BARBOSA (1974) had already registered 

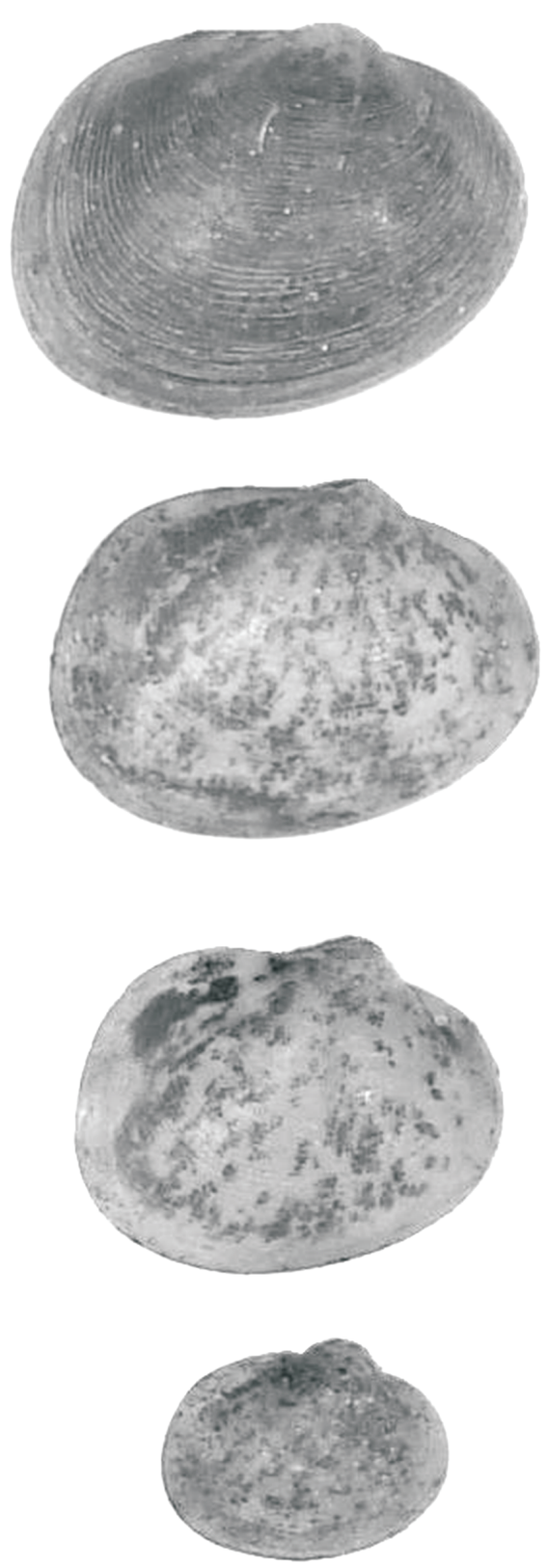

Figure 35. Eupera cubensis (Prime, 1865) (MCN-MOL 38845). Size differences of the specimens associated with Radiospongilla crateriformis (Potts, 1882) MCN-POR 6994.

sphaerid bivalves of genus Eupera Bourguignat, 1854 living inside sponges of genera Trochospongilla, Drulia Gray, 1867 and Metania Gray, 1867 encrusted on the bark of trees affected by the Amazonian seasonal floods. In the present study, no superimposition of the sponges over the bryozoans or vice-versa was found, though the samples and surfaces occupied were small, suggesting the absence of competition for substrate among the three faunal groups considered.

Hence, the association of these three distinct groups of benthic, sessile and filter-feeding animals, in a markedly seasonal environment with high levels of POC, is justified by two basic factors. The first consists in the asexual production of anatomical resistance mechanisms, particularly to drought, such as the statoblasts and sessoblasts of Bryozoans, and the gemmules of sponges. In the particular case of the genus Eupera the possibility had already been considered that these minute bivalves, attached to substrate by byssus, resist dry periods (Volkmer-Ribeiro \& De Rosa-Barbosa, 1974). Remembering that HERRINGTON (1962) reported remarkable adaptations of freshwater Sphaeridae of North America to habitats subjected to droughts which last several months each year. IRMLER $(1978,1989)$, when studying the fauna of the flood-prone forest of the Central Amazon area distinguished adaptations to the changes in water level experienced by the communities of land and aquatic animals. Of particular note within this latter group is Eupera simoni (Jousseaume, 1889), found permanently within the flood zone, but that makes use of the differentiated seasonal rhythms, entering in diapause prior to the dry period and into accelerated reproduction as soon as the flood period starts, which results in a large number of young present in the population during the season of floods. This clear difference in size can be seen in the specimens illustrated in Fig. 35.

UsSEGLIO-Polatera et al. (2000), on their assay of grouping benthic freshwater macroinvertebrates following common biological/ecological traits had Porifera and Bryozoa clustered together on account of they being filter feeders, sessile and producers of asexual resistant bodies. On the other hand STUART \& KLUMPP (1984), upon a study of particle-size selection and foodresource partitioning among marine benthic filter feeders which commonly depend on the suspended particulate organic material in the media (an ascidia, 3 bivalves and a sponge) demonstrated that: "a mixed assemblage of sponges and bivalves may be able to utilize the suspended material more efficiently than a single-species population, due to recycling of some of the particles".

Acknowledgments. The senior author acknowledges CNPq for the research fellowship and corresponding grant. We acknowledge M.Sc. Scott A. Roush's careful sampling and keen observation of a common appropriation of the habitat by Bryozoans and Sponges as well for the material and the geographical positioning of the sampling stations; Dr. Maria Cristina Dreher Mansur of Museu de Ciência e Tecnologia, Pontifícia Universidade Católica do Rio Grande do Sul (PUC), for the identification of the Eupera species; M.Sc. Silvia Drügg Hahn, curator of the Bivalve Collection of MCN-FZB for the deposit and cataloguing of the Eupera cubensis specimens; an unidentified referee and Dr. Eduardo Hajdu of Museu Nacional/UFRJ, Rio de Janeiro, for the valuable suggestions offered

\section{REFERENCES}

Bass, D. \& VolKMER-Ribeiro, C. 1998. Radiospongilla crateriformes (Porifera: Spongillidae) in the West Indies and taxonomic notes. Iheringia, Série Zoologia, 85:123-128.

Bonetto, A. A. \& Ezcurra de Drago, I. D. 1973. Las esponjas del genero Trochospongilla Vejdovsky en águas Argentinas. Physis B32 (84):13-18.

Debrot, A. O. \& VAn-Soest, R. W. M. 2001. First records of the freswhater sponges Corvoheteromeyenia heterosclera and Spongilla alba (Porifera: Spongillidae) from Curaçao, with species descriptions and data from transplantation experiments. Caribbean Journal of Science 37(1-2):88-94.

Ezcurra de Drago, I. 1974. Las espécies sudamericanas de Corvomeyenia Weltner (Porifera: Spongillidae). Physis B 33(87):233-240. 
1979. Un nuevo género sudamericano de esponjas: Corvoheteromeyenia gen. nov. (Porifera Spongiliidae). Neotropica 25(74):109-118.

Frost, T. M. 1991. Porifera. In: Thorp, J. H. \& Covich, A. P. eds. Ecology and classification of North American freshwater invertebrates. New York, Academic. p.5-124.

Herrington, H. B. 1962. A revision of the Sphaeridae of North America (Mollusca: Pelecypoda). Miscellaneous Publications, Museum of Zoology, University of Michigan 118:1-74.

IRMLER, U. 1978. Matas de inundação da Amazônia Central em comparação entre águas brancas e pretas. Ciência e Cultura 30(7):813-821.

1989. Die Fauna der Zentralamazonischen Überschwemmungswälder: Verbreitung, Anpassung und Bedeutung. In: Hartmann, C. ed. Amazonien im Umbruch. Berlin, Reimer. p.227-243.

Jones, M. L. \& RutZleR, K. 1975. Invertebrates of the upper chamber, Gatun Locks, Panama Canal, with emphasis on Trochospongilla leidii (Porifera). Marine Biology 33(10):57-66.

Manconi, R. \& Pronzato, R. 2005. Freshwater sponges of the West Indies: Discovery of Spongillidae (Haplosclerida, Spongillina) from Cuba with biogeographic notes and a ckecklist for the Caribbean area. Journal of Natural History 39(36):3235-3253.

Meek, S. E. 1908. Zoology of Lakes Amatelan and Atitlan, Guatemala, with special reference to the ichthyology. III Field Museum of Natural History Publications, Zoological Series 7:159-206.

Murillo, R. \& Mora, M. 1995. Presencia de Ephydatia fluviatilis (Porifera: Spongillidae) en Costa Rica. Revista de Biologia Tropical 42(3):761

Old, M. C. 1936. Yucatan freshwater sponges. In: Pearse, Creaser \& Hall eds. The cenotes of Yucatan. Carnegie Institut Publication. $\mathrm{n}^{\circ}$ 457, p.29-32.

Penney, J. T. \& Racek, A. A. 1968. Comprehensive revision of a worldwide collection of freshwater sponges (Porifera: Spongillidae). Proceedings of the United States National Museum 272:1-184.

Poirrier, M. A. 1976. A taxonomic study of the Spongilla alba, Spongilla cenota, Spongilla wagneri species group (Porifera: Spongillidae) with ecological observations of Spongilla alba. In: Harrison, F. W. \& Cowden, R. R. eds. Aspects of Sponge Biology, New York, Academic. p.203-213.

1977. Systematic and ecological studies of Anheteromeyenia ryderi (Porifera: Spongillidae) in Louisiana. Transactions of the American Microscopical Society 96:62-67.

1982. Porifera. In: Hurlbert, S. H. \& Villalobos-Figueroa, A eds. Aquatic Biota of Mexico, Central America and the West Indies. San Diego, San Diego State University. p.59-61.

Poirrier, M. A. \& Trabanino, S. 1989. Freshwater sponges (Porifera: Spongillidae) from Lake Ilopango, El Salvador, with observations on spicule malformation in Spongilla alba. Transactions of the American Microscopical Society 108(2):211-214

Potts, E. 1882. Three more freshwater sponges. Proceedings of the Academy of Natural Sciences of Philadelphia 34:12-14.

1887. Contributions towards a Synopsis of the American forms of freshwater sponges with descriptions of those named by other authors and from all parts of the world. Proceedings of the Academy of Natural Sciences of Philadelphia 39: $158-279$.

Rioja, E. 1953. Estudios Hidrobiológicos. XI. Contribución al estudio de las esponjas de agua dulce de Mexico. Anales del
Instituto de Biologia de la Universidad de Mexico 24:425-433

Roush, S. A. 1999. Freshwater sponges (Porifera: Spongillidae) of the Guanacaste Conservation area, Costa Rica: a preliminary survey. Memoirs of the Queensland Museum 44:540.

2000. Distribution Pattern and Habitat Preference of Phylactolaemate Bryozoans in the Guanacaste Conservation Area, Costa Rica. In: INTERNATIONAL BRYOZOOLOGY ASSOCIATION CONFERENCE, $11^{\text {th }}$, Balboa, 2000, Proceedings... Balboa, Smithsonian Tropical Research Institute. p.336-342.

Smith, D. G. 1994. First report of a freshwater sponge (Porifera: Spongillidae) from the West Indies. Journal of Natural History 28(5):981-986.

Stuart, V. \& Klumpr, D. W. 1984. Evidence of food-resource partitioning by kelp-bed filter feeders. Marina Ecology Progress Series 16:27-37.

Tavares, M. C. M.; Volkmer-Ribeiro, C. \& De Rosa-Barbosa, R. 2003. Primeiro registro de Corvoheteromeyenia australis (Bonetto \& Ezcurra de Drago) para o Brasil com chave taxonômica para os poríferos do Parque Estadual Delta do Jacuí, Rio Grande do Sul, Brasil. Revista Brasileira de Zoologia 20(2):169-182.

Usseglio-Polatera, P.; Bournaud, M.; Richoux, P. \& Tachet, H. 2000. Biological and ecological traits of benthic freshwater macroinvertebrates: relationship and definition of groups with similar traits. Freshwater Biology 43:175-205.

Volkmer-Ribeiro, C. 1981. Porifera. In: Hurlbert, S. H.; Rodriguez, G.; Santos, N. D. eds. Aquatic biota of tropical South America. San Diego, San Diego State University:86-95.

1985. Manual de técnicas para a preparação de coleções zoológicas 3. São Paulo, Sociedade Brasileira de Zoologia, CNPq. $6 \mathrm{p}$.

1992. The freshwater sponges in some peat-bog ponds in Brazil. Amazoniana 12(2):317-335.

Volkmer-Ribeiro, C. \& Batista, T. C. A. 2007. Levantamento de cauxi (Porifera, Demospongiae), provável agente etiológico de doença ocular em humanos, Araguatins, rio Araguaia, Estado do Tocantins, Brasil. Revista Brasileira de Zoologia 24(1):133-143.

Volkmer-Ribeiro, C.; Correia, M. M. F.; Brenha, S. L. A. \& MendonçA, M. A. 1999. Freshwater sponges from a Neotropical sand dune area. Memoirs of the Queensland Museum 44:643-649

Volkmer-Ribeiro, C. \& De Rosa-Barbosa, R. 1974. A freshwater Sponge-Mollusk Association in Amazonian Waters. Amazoniana 5(2):288-291.

Volkmer-Ribeiro, C. \& Machado, V. S. 2007. Freshwater sponges (Porifera, Demospongiae) indicators of some coastal habitats in South America: redescription and key to identification. Iheringia, Série Zoologia, 97(2):157-167.

Volkmer-Ribeiro, C.; Mansur, M. C. D.; Mera, P. S. \& Ross, S. M. 1998. Biological indicators in the Aquatic Habitats of the Ilha de Maracá. In: Milliken, W. \& Ratter, J. A. eds. The Biodiversity and Environment of an Amazonian Rainforest. Chichester, John Wiley. p.403-414.

Volkmer-Ribeiro, C. \& Pauls, S. M. 2000. Esponjas de Agua Dulce (Porifera, Demospongiae) de Venezuela. Acta Biologica Venezuelica 20(1): 1-28

Volkmer-Ribeiro, C. \& Traveset, A. 1987. Annotated Catalogue of the Type Specimens of Potts' Species of Freshwater Sponges. Proceedings of the Academy of Natural Sciences of Philadelphia 139:223-242.

Volkmer-Ribeiro, C. \& TurCQ, B. 1996. SEM analysis of silicious spicules of a freshwater sponge indicate paleoenvironmental changes. Acta Microscópica 5(B):186-187 